\title{
Comparative Perspectives on East and West European Defence Industries*
}

\author{
Brian Kenny $^{* *}$
}

Coupled with the continuing threat of reduced defence expenditures and increasing competition, European defence companies have reacted with a number of strategic manoeuvres involving mergers, acquisitions and other forms of alliance. Moves towards a single European defence industry have been a focus for discussion among major EU member countries for some time and the integration of defence aerospace organisations seems well placed to succeed with the advent of 'EADS'. Defence industry firms and managers from the former Visegrad countries appear to share similar experiences and cultural characteristics with their western counterparts. With their recent incorporation of the Czech Republic and Poland into NATO, their integration into a wider European defence industry could be a viable option. However, there are particular economic, political, cultural and managerial problems to be faced and surmounted before wider and fuller integration can be achieved.

Europäische Unternehmen der Rüstungstechnik reagieren auf die Gefahren weiterer Budgetkürzungen der Verteidigungshaushalte und zunehmenden Konkurrenzdruckes mit strategischen Umstrukturierungen, vor allem Fusionen, Übernahmen und anderen Formen von Unternehmenszusammenschlüssen. Die größeren EU-Mitgliedsstaaten diskutieren Wege zu einer vereinten europäischen Rüstungsindustrie, und die Integration von Unternehmen der Rüstungs-, Luft- und Raumfahrttechnik geht gut voran. Manager von Unternehmen der ehemaligen Visegrad-Staaten haben vieles mit ihren westlichen Kollegen in punkto Persönlichkeit und Erfahrungen gemein. Eine NATO-Erweiterung in dieser Richtung bietet dann auch die Möglichkeit einer ebenso ausgedehnten vereinten europäischen Rüstungsindustrie.

\footnotetext{
* manuscript received: 17.05.1999, revised: 17.09.2000, accepted: 18.09.2000;

** Brian Kenny, b.1935, Department of Economics and Business Studies, Huddersfield University Business School; Subject specialisms include corporate and business strategy and marketing. Research interests cover strategy and structure in high technology industries (including the defence industry), small business management and Eastern European transformation.
} 


\section{Introduction}

The continuing threat of lower armament levels presents a challenge to a unified Europe as the prospect of smaller weapons production runs and increasing complexity of weapons, accentuate both the already limited scale-effects and the inevitable wastage due to duplicated R\&D efforts. The signing of the NATORussia Founding Act in May 1997 and NATO's conditional acceptance of the Czech Republic, Hungary and Poland in the following December, represent somewhat of an upheaval for European defence and security. The earlier moves toward unification of Western Europe, the thawing-out of the cold war and the revolutions of Eastern Europe provided opportunities for the rationalisation of European defence and the associated, national military-industrial bases. Increasing global competition has led to greater consolidation in the European aerospace and defence industry, in spite of pressures to preserve national interests; while the pursuance of defence business alliances $\mathrm{n}$ western and central European countries is at least in part, an acknowledgement of the acceptance of some of the these latter countries into NATO. There are clearly limited long-term survival options for the major west European defence companies and their east European counterparts. Whether competing in the international arms market or diversifying into the civil sectors, change and cultural harmony represent a challenge for management on both sides.

\section{Defence Industry Perspective}

\section{European Defence Procurement and Production}

The main policy body for European defence procurement issues is the Western European Armaments Group which was set up in 1992 as part of the Western European Union to encourage co-operation in defence procurement. This was driven by a desire to increase the opportunities for the different defence ministries to reap the advantages of savings in procurement and to increase the opportunities for defence equipment exports.

Defence equipment procurement in Europe accounted for almost 22 percent of NATO defence spending in 1995 (See table 1). Including research and development and in-service support, the figure was in the region of 30-40 per cent.

European arms sales amounted to almost $\$ 58$ billion in 1996, led by British Aerospace of the UK, Thomson of France and Germany's Daimler Benz. Sales of the major US defence companies however, outstripped the collective European total by some 48 per cent at $\$ 84 \mathrm{bn}$, with top supplier Lockheed Martin accounting for more than 20 per cent (see table 2). 
Table 1 Estimates of European Military Expenditure, 1995-97 (in US\$ at 1995 prices and exchange rates)

\begin{tabular}{|l|c|c|c|c|}
\hline & 1995 & $\begin{array}{c}\text { \% spent on } \\
\text { equipment in } \\
1995\end{array}$ & 1996 & 1997 \\
\hline Belgium & 4,572 & 06.3 & 4,362 & 4,410 \\
\hline Denmark & 3,107 & 14.0 & 3,126 & 3,170 \\
\hline France & 40,541 & 23.9 & 45,596 & 47,061 \\
\hline Germany & 34,023 & 11.6 & 40,343 & 39,106 \\
\hline Greece & 3,382 & 24.4 & 5,359 & 5,702 \\
\hline Italy & 16,038 & 17.3 & 21,369 & 21,582 \\
\hline Netherlands & 8,557 & 18.4 & 8,076 & 8,014 \\
\hline Norway & 3,772 & 21.2 & 3,696 & 3,591 \\
\hline Portugal & 1,689 & 08.1 & 2,573 & 2,815 \\
\hline Spain & 7,003 & 14.0 & 8,451 & 8,342 \\
\hline Turkey & 6,239 & 39.7 & 7,396 & 7,461 \\
\hline UK & 34,481 & 30.7 & 34,096 & 32,837 \\
\hline US & 252,600 & 17.7 & 271,417 & 272,955 \\
\hline
\end{tabular}

Source: Adapted from The International Institute for Strategic Studies (1995) and SIPRI (1998: 221-223)

\section{Arms Transfers and Exports}

In 1996, the total value of arms exports for the major exporting countries at current prices amounted to more than US\$27bn, with the United States accounting for more than 46 per cent of this figure (SIPRI, 1998). In 1997, the US held 43 per cent of the arms supply market with France and Russia each holding about 13 percent followed by the UK with just over 10 per cent of the market (see table 3). 
Table 2 World's Top 20 Defence Companies 1996 (in US\$bn)

\begin{tabular}{|c|c|c|c|c|}
\hline \multirow[b]{2}{*}{ Company } & \multirow[b]{2}{*}{ Country } & \multirow[b]{2}{*}{$\begin{array}{c}\text { Arms } \\
\text { sales }\end{array}$} & \multicolumn{2}{|c|}{ \%Total Profit } \\
\hline & & & sales & (US\$Mn) \\
\hline Lockheed Martin & US & 18.01 & 67 & 1347 \\
\hline Mcdonnell Douglas & US & 9.50 & 69 & 88 \\
\hline British Aerospace & UK & 8.34 & 72 & 486 \\
\hline Northrop Grumman & US & 6.70 & 83 & 234 \\
\hline General Motors & US & 6.66 & 4 & 4963 \\
\hline Hughes Electronics (GM) & US & 6.34 & 40 & 1029 \\
\hline Thomson & France & 4.57 & 32 & -466 \\
\hline Thomson - CFS (Thomson) & France & 4.54 & 64 & 146 \\
\hline GEC & UK & 4.46 & 26 & 637 \\
\hline Raytheon & US & 4.03 & 33 & 761 \\
\hline Boeing & US & 4.00 & 18 & 1182 \\
\hline $\mathrm{DCN}$ & France & 3.47 & 98 & -37 \\
\hline United Technologies & US & 3.38 & 14 & 906 \\
\hline Daimler-Benz & Germany & 3.36 & 51 & 861 \\
\hline TRW & US & 3.36 & 34 & 480 \\
\hline DASA (DB) & Germany & 3.33 & 38 & 799 \\
\hline General Dynamics & US & 3.31 & 92 & 353 \\
\hline IRI (Finnmeccia) & Italy & 2.74 & 6 & 151 \\
\hline Aerospatiale & France & 2.31 & 23 & 279 \\
\hline Rolls Royce & UK & 2.01 & 30 & -73 \\
\hline
\end{tabular}

\footnotetext{
Source: Adapted from SIPRI (1998 : 261-2))
} 


\section{Defence Industry in East and Central Europe}

The collapse of the Warsaw Treaty Organisation (WTO), cuts in military expenditure, withdrawal of state subsidies and increasing political and economic problems of developing countries - important customers for arms - led to a fall in overall production by some 75 per cent of the levels recorded in the late 1980's. Even at that time, military production was in rapid decline. The major arms producers in the former Czechoslovakia numbered about eleven, spread over a variety of heavy and light engineering equipment and concentrated mainly (73 per cent of the workforce employed in defence production) in southern Moravia, the central Slovak region and around the capital, Prague.

Table 3 Top Major Conventional Weapons Suppliers, 1993-1997 (in US\$bn@ 1990 prices)

\begin{tabular}{|l|c|c|c|c|c|c|}
\hline & $\mathbf{1 9 9 3}$ & $\mathbf{1 9 9 4}$ & $\mathbf{1 9 9 5}$ & $\mathbf{1 9 9 6}$ & $\mathbf{1 9 9 7}$ & $\begin{array}{c}\text { Est. \% of world market } \\
\text { (1997) }\end{array}$ \\
\hline U S & 12.50 & 10.43 & 9.82 & 9.53 & 10.84 & 43.10 \\
\hline Russia & 3.54 & 1.12 & 3.22 & 3.90 & 3.47 & 13.58 \\
\hline France & 0.90 & 0.70 & 0.81 & 2.00 & 3.34 & 13.28 \\
\hline UK & 1.56 & 1.51 & 1.73 & 1.98 & 2.63 & 10.45 \\
\hline
\end{tabular}

Source: Adapted from SIPRI (1998 : 294)

Szayna (1995:135) points out the sharp decline in the Polish defence budget allocations and how this significantly influenced the economic position and functioning of the arms industry. In the decade to 1993 the volume of military production fell (in constant 1994 prices) by 80 per cent which was reflected in falling defence procurement from $33 \mathrm{~b}$ zloty to $5.3 \mathrm{~b}$ zloty at 1994 constant prices). At the beginning of 1994 over 350 firms were involved in defence production covering a variety of equipment including small arms, ammunition, anti tank missiles, anti aircraft guns, telecommunication equipment, tanks, transport lightweight and training aircraft, helicopters, military vehicle engines and shipbuilding. According to Perczinski, et. al. (1995), it was estimated that bulk of this was covered by 42 firms of which only 20 achieved a net profit in 1993; in that year the financial indebtedness of these companies exceeded 14.7 bn zloty.

By 1993 bilateral agreements on East-West military Co-operation helped stem the decline and establish a leaner and restructured, if somewhat diminished, defence industry base. The developments gave rise to increased interest on the part of Western defence companies to co-operate with their ECE counterparts which was, according to Kiss (1997), deemed to be a prerequisite to doing 
business as ECE national armed forces were encouraged to purchase local products.

Military expenditure in Poland and the Czech Republic remained relatively stable over the five year period to 1997 (table 4), the combined spend on defence equipment being less than that of Denmark in 1995, to give an indication of the level of activity. In 1999 almost all of the major producers in both countries (9 in the Czech Republic and 15 in Poland) and were under 100 per cent state ownership with the exception of Aero Vodochody of the Czech Republic - 35\% held by Boeing Ceska - and Polish helicopter company PLZ Swidnik - 40\% held by employees and banks (Defence Systems Daily, January 2000).

Table 4 Trends in Military Expenditure 1993-97 (US\$m at 1995 prices)

\begin{tabular}{|l|c|c|c|c|c|}
\hline \multicolumn{7}{|l|}{} & 1993 & 1994 & 1995 & 1996 & 1997 \\
\hline Poland & 2773 & 2675 & 2720 & 2853 & 2935 \\
\hline Total military expenditure & 343 & 295 & 294 & 240 & 287 \\
\hline Spent on equipment & 2.5 & 2.4 & 2.3 & 2.8 & 3.1 \\
\hline Total as a \% of GDP & 1031 & 965 & 900 & 902 & 880 \\
\hline Czech Republic & 25 & 77 & 112 & 131 & 112 \\
\hline Total military expenditure & 2.5 & 2.3 & 1.9 & 1.8 & 1.9 \\
\hline Spent on equipment &
\end{tabular}

Source: Adapted from: SIPRI (1998 : 210)

In central and eastern Europe, as far as the published figures go, the most successful arms exporter appears to have been the Czech Republic whose military exports amounted to US\$167m in 1993 and totalled some US $\$ 465 \mathrm{~m}$ from 1994 to 1996. By comparison, Poland as the next largest exporter of this group, delivered weapons and equipment worth an estimated US\$60m in 1993 (SIPRI, 1998)

\section{Industry Strategies}

\section{Conversion and Diversification}

From an industry viewpoint the 'remain-exit' considerations have generally set tough questions not only for the major participants, but also for the many 
thousands of SMEs in the sub-contracting sectors. On the one hand, there is the trend towards 'commercialisation' of the defence market due to pressures for greater competition and the tendency to seek 'value for money' through the issue of fixed-price contracts. On the other hand, diversification into the highly volatile, competitive and often hostile non-defence product/market arenas is considered to be the only route for survival.

Smith and Smith (1992), summarised the strategic options open to defence companies as consolidation, diversification, and conversion (exit). Consolidation as a strategic option for a defence company facing the declining market is sometimes described as "acquiring a larger piece of the smaller cake". This is the typical objective of mergers and acquisitions which have been executed in the western defence industry to a remarkable extent throughout the recent years. The rationale behind this may be the comparatively low risk which companies associate with their "sticking to the knitting". Other alternatives would direct companies towards civilian markets where they would have to cope with significant problems resulting from their traditional defence-oriented culture. However, the option to consolidate is only open to the strong companies with a dominant market position, strong strategic partnerships and firm capital bases.

The situation may be different if conversion is the goal, with the defence company seeking to engage exclusively in civilian activities, either as a whole or within some part of its capacity. In the early days of the decline of the defence business, this was perceived as the obvious solution to survival, in particular by those defence companies which had strong $\mathrm{R}$ and $\mathrm{D}$ resources. It was generally felt that their leading edge technologies would enable them to develop civilian products beyond the present state-of-the-art. As a result conversion became a popular subject in public discussions about the future of the defence industry participant organisations.

The major reason for the frustrating result of the extensive conversion efforts in the German defence industry is one on which most analysts of this subject are agreed. It is, again, the defence-specific culture which inhibits any effective engagement in civilian products and markets. A defence oriented company culture and management style generally militate against civilian success and cultural obstacles make the chances of spin-off from defence technology rather limited. Nevertheless, conversion has been successful in a few individual cases, the most prominent example in Germany being Krauss-Maffei the major German source for Main Battle Tanks which subsequently achieved $75 \%$ of its turnover from civilian activities. However, organisational and management structures had to be changed dramatically in favour of flexibility, customer awareness, lean production, and lean administration and most importantly, this involved the very early separation of the civilian and defence business units from each other. 
Because conversion activity appears to have been a reaction to the downturn in demand for defence equipment, it is hardly surprising that there have been few successes both at a European and an international level. For example, there obviously has to be a feasible market opportunity in addition to organisational flexibility.

Genuine conversion of industry to civilian production implies a radical change in the way the economy is managed. At the macroeconomic level the patterns of investment, enterprise and resource allocation in a military command economy are completely different from those in a civilian market economy. In a command economy, the starting-point is military security and, for East-Central Europe in the context of the cold war, bloc security. In a civilian economy these decisions are determined by natural and social resources and the exploitation of comparative advantages. In a command economy there is a strong central and vertical system for both decision making and dependence in which economic units are primarily connected to each other through the centre. There is also a tendency towards strong monopoly. In a civilian economy, multiple and diverse economic agents interact with each other through a flexible network of both horizontal and vertical contacts.

According to Kiss (1997: 200) conversion in the east European defence industries following the break up of the Soviet Union, was largely left to market forces and the efforts of individual enterprises. However, the quasi-market economy that developed during transition did not particularly facilitate the conversion to civilian production, nor were other economic conditions helpful such as interest rates, access to credit and taxes. For the defence enterprises, survival was an overriding driving force and the technological, economic and psychological bonds with military production were still very dominant.

Many enterprises achieved partial conversion or introduced new civilian products alongside defence-related activities. This diversification did not however, bring major changes in the way the enterprise functioned. The principal function was to help the enterprises survive, often until military demand was revived. In these cases the same poor and rigid planning, inflexibility and inefficiency that in general characterised military production were also characteristic of conversion projects and "new products were manufactured without market research or much attention to design or cost efficiency" (Kiss : 178).

Changes in the defence sector will no doubt have wider implications, such as regional and technology policy. It has been acknowledged that technological benefits do arise from large-scale investment in high capital defence contracts and that Europe should, in view of the inevitable rundown in the industry, address this issue in terms of say 'collective diversification'. There is however still considerable pressure from some quarters to develop and sustain a healthy European defence industry and this preoccupation may seem at the expense of 
industry diversification/conversion attention. It has been suggested that the Europe's focus should be more concerned with long-term defence policy and the requisition of appropriate military hardware (i.e. a sound European defenceindustrial base) than with the requirements of possible defence conversion policies. Only by using this 'Europeanisation' channel could the separate defence industries capitalise on their strengths and continue to play a leading role in the future of European defence.

The growth over the years of specialised defence firms, strong barriers to entry, increased industry concentration and powerful pressure group activity are factors which appear common to the major member countries. As a whole, this represents a significant 'military-industrial' force which has often been regarded as a threat to European-wide conversion and of course, is greatly exacerbated by increasing cross-border activity. For example mergers and acquisitions, strategic alliances and ultimately, the unification of the industry. This argument of course, assumes that exit from the industry should be an end objective in its own right as opposed to merely a "survival option".

\section{Collaboration, Mergers and Alliances}

Coupled with the continuing threat of reduced defence expenditures, major companies have reacted to the changes with a number of strategic moves involving domestic and international mergers and acquisitions, niche markets and diversification, in addition to lay-offs and plant closures. In military aviation the overall cost of design, research, development and production of modern fighter aircraft, has inevitably led to a strategy of co-production among European partners. Aerospace is synonymous with high technology developments in engines, materials, avionics and the associated sophisticated manufacturing techniques, while collaboration programmes such as the Eurofighter, represent a classic example of a high performance, cost-sharing exercise - a programme shared by the UK (33\%), Germany (33\%), Italy (21\%) and Spain (13\%) and estimated at $£ 42 \mathrm{bn}$ at current rates.

However, collaborative projects have not always gone smoothly and generally, higher costs have arisen due to delays, communication problems, national sensitivities and the inherent complications due to the geographical separations. Genuine economies of scale and the eradication of expensive R\&D duplication, can best be achieved by full merger as past partnership experiences such as the Eurofighter quoted above, appeared not to have achieved the efficiency improvements necessary for international competitiveness (Sunday Times, 6 September, 1998).

There has been significant cross-border activity involving the major defence equipment producers over the past decade including the purchasing of Philips' military activities by Thomson of France, GEC's acquisition of Ferranti Defence Systems and Daimler Benz's takeover of Messerchmitt-Bokon-Blohm 
(Germany's main aerospace and missile company) in the early 1990's. More recently, the British Aerospace and Daimler-Benz joint venture arm Dasa, bought the defence electronics interests of German company Siemens; BAe's other joint venture with Lagardere of France, Matra BAe Dynamics, took a 30 per cent interest in Dasa's missile subsidiary. GEC Marconi, the defence division of UK company GEC, merged some of its defence electronics and missiles business in a joint venture with Alenia of Italy and developed a sonar-related joint venture with Thomson-CFS in 1996. Thus, cross-border alliances rather than acquisitions or outright mergers, appeared to dominate.

The extent of alliances by the end of 1998 can be judged from figure 1, although the picture had changed and by the end of 1999, with BAe Systems' take-over of GEC's defence business. By this time, moves towards a single European aerospace industry were taking shape in the form of the European Aeronautic Defence and Space Company (EADS). This was formed by a merger of France's Aeropsatiale-Matra, Germany's DaimlerChrysler Aerospace (Dasa) and Construcciones Aeronautica SA (CASA) of Spain, with BAe Systems being a 20 per cent shareholder via its existing ventures. In August 2000, EADS was launched simultaneously on the French, German and Spanish stock markets.

\section{East-West Contracts and Alliances}

Stimulated by the promise of NATO membership and increased activity on the arms front, several defence equipment contracts were in hand in the ECE states, at the end of 1997. Boeing McDonnell Douglas which supplied the avionics for a Czech light jet, had bid for a contract to provide similar equipment for a Polish helicopter while Elbit of Israel hoped to sell military radars to the same country. Hungary had ordered $\$ 100 \mathrm{~m}$ worth of missiles from Matra of France and the Czech government was expected to put out a tender for the supply of up to 36 fighter aircraft worth up to \$1.6bn in early 1998 (The Economist, 8 November, 1997 pp 98-103).

Lockheed Martin of the US had, by late 1997, already aligned itself with the Czech engineering group CKD, British Aerospace with Chemopol Machinery and Boeing with Skoda Plzen to supply the F-16 fighter, the BAe/Saab Gripen, or the F-18, respectively. Boeing also negotiated a substantial stake in the Czech aviation company Aero Vodochody. It was intimated at the time that if the Czech Republic chose the US F-16 or F-18 fighters it would become a subcontractor, whereas opting for the Gripen would make it part of an integrated European aerospace industry (Central European Business Weekly, November 7/13, 1997).

The Polish shipbuilding industry entered into a contract with British Aerospace SEMA (BaeSEMA) and British Marine Technology (BMT) to develop, construct and support a fully integrated warship solution compatible with NATO operational requirements. British Aerospace had also been active in establishing 
partnership for production of its new Hawk trainer aircraft. In August 1998, a contract for the manufacture of airframe parts and associated tooling was awarded to Polish aerospace company PZL Mielec. The latter was - in British Aerospace's terms - designated to become a strategic supplier to BAe's worldwide aerospace and defence programmes and the venture was seen as the "start to Poland's involvement in the future of the European aerospace industry" (Central European Business Weekly, July 24/August 13 1998).

Poland, a keen advocator of NATO membership, was originally expected to purchase 100 to 160 new fighters to replace older Russian made aircraft, while Hungary's requirements were estimated to be close to the Czech number. However, the budgetary pressures and accompanying uncertainties were already emerging in mid 1998 when the Polish government indicated it might lease older aircraft from the United States at a low cost rather than buy new aircraft from Boeing, Lockheed Martin or the British Aerospace-Saab consortium. As in the Polish case, the Czech government was also having second thoughts about the early purchase of new fighter planes.

\section{Future Integration}

It is acknowledged that Europe requires a wider and more integrated defence industry in order to enhance its security identity and to compete as well as cooperate with powerful US defence companies. In its absence, the Union is unlikely to achieve its own political potential as an effective foreign policy agent. Likewise, as Cook (1999) suggests, ECE defence firms 'must identify and exploit potential synergies between military and civilian products, particularly in optics, electronics and specialised materials. This requires that defence firms tie into broader networks of investment, production and trade' $\mathrm{He}$ also points out that this would involve greater co-operation amongst ECE defence companies in collaborating with their western counterparts and in procuring new systems.

Figure 1 Major European Defence Aerospace Alliances - 1999 


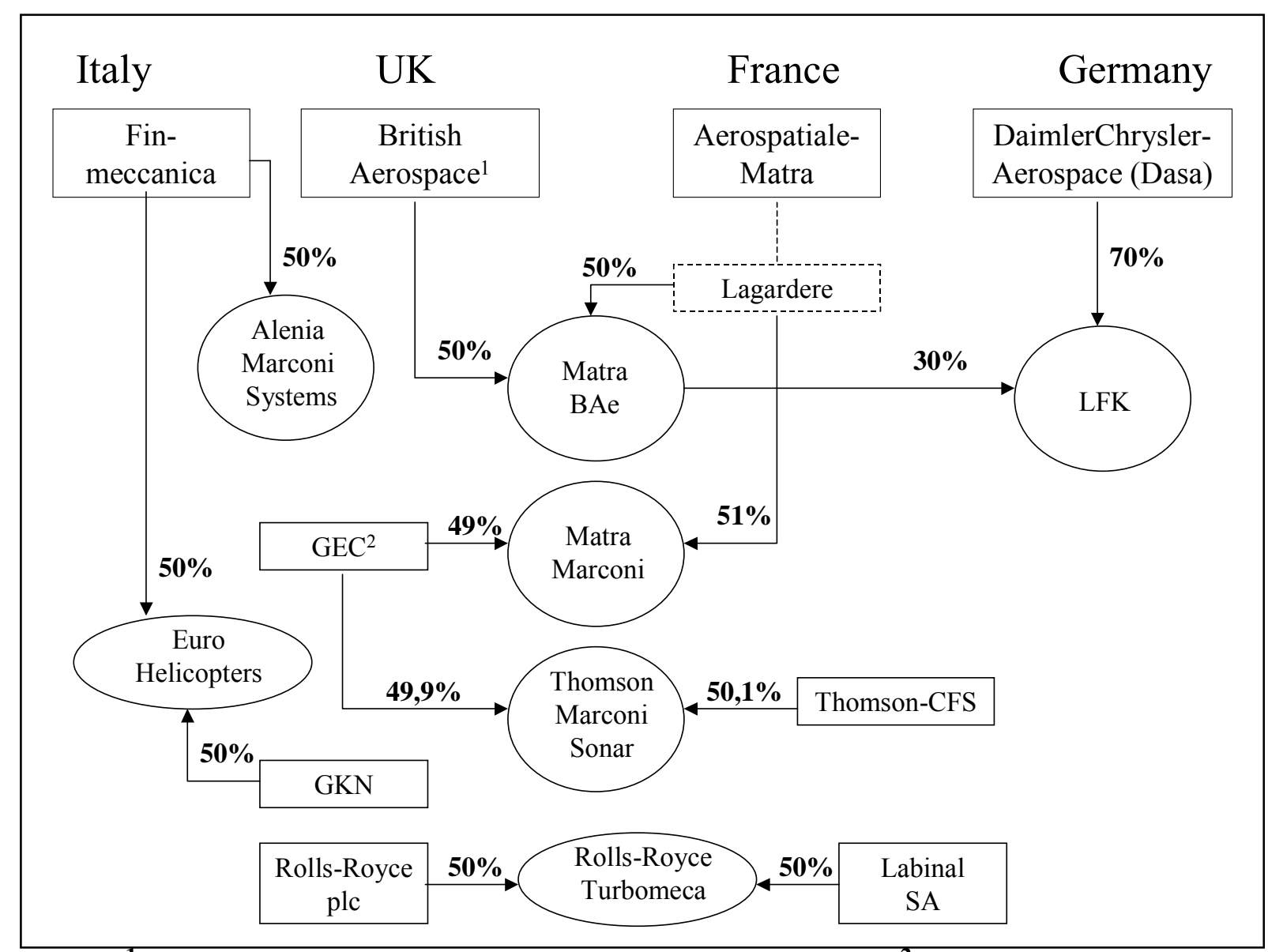

Notes: ${ }^{1}$ Now British Aerospace Systems (BAe Systems); ${ }^{2}$ GEC defence business absorbed within BAe Systems

Data Sources: Financial Times September 31998 and Defence Systems Daily 4 January 2000

The latter collaboration has potential for real cost savings and the development of trust among partner states, even though it may lead to some loss of control over their national defence-industry complexes. However, ECE firms may also be obliged to respond to marketing pressure from American defence firms, as well as participating in European mergers. The region's defence industries are in need of FDI and the states' leaders are unlikely to easily discriminate between American or European firms seeking to acquire shares in local companies. Other, strategic alternatives point to focusing on specialised defence equipment where they can apply certain skills and/or cost advantages.

\section{Market and Magagerial Implications}

\section{Industry and Market Dynamics}

In relation to the defence industry, 'market forces' have traditionally been down to individual governments as single buyers (monopsonistic), which determine the structure and size of domestic arms markets through distribution of defence 
contracts. Some West European governments have inhibited competition in a number of ways including preventing companies from achieving greater specialisation in defence sectors through trans-national consolidation, which is their best protection against being acquired by national conglomerates. Also, by giving primacy to national autonomy thus reducing competition and thereby driving up costs and inhibiting innovation. Governments justify these extra costs on the grounds that their national base for key strategic defence and dual-use technologies should be maintained (IISS, 1998). Thus the notion of 'market forces ' driving defence industrial restructuring is somewhat misleading.

Domestic defence markets bear little resemblance to consumer or industrial markets, where there tend to be many buyers and suppliers and where the influence of traditional 'market forces' is more appropriate. Among those differentiating key characteristics of the defence industry, the major ones which are usually mentioned are cost-plus mentality, lack of marketing skills and the aim to provide maximum technical performance in the light of long-lasting development times applicable. Additionally, many western European defence companies are considered to have bureaucratic planning procedures, or no planning procedures at all (Arthur D Little, 1996); the defence industry has traditionally, adapted to a situation of stability and long time horizons (Kenny and Stessen 1996); governments determine the rules under which contracts are negotiated and agreed, emphasising weapons' performance rather than cost and elaborate rules and regulations to ensure public accountability (Southwood, 1992).

According to Kiss (op cit: 137) many ECE defence enterprises were given resources to establish their own internal supplier and infrastructure system so that production would not fail under any circumstances and they also benefited from inter-ministerial co-operation, which was not available to other sectors. The state 'cushioned' defence enterprises at both ends of the production chain. Enterprises did not have to worry about selling their output. Interstate agreements guaranteed stable markets, with fixed prices and high profits built in. In each country a monopolist trade agency, specialised in the arms trade, executed agreements concluded by the authorities The state also generally ensured critical inputs for military production whole network of subcontractors providing energy, raw materials, equipment labour or performing some special technical service was organised ministries to ensure that military-related production continued smoothly.

\section{Cultural and Managerial Issues}

Beyond the special features of the social situation and management system, the basic rationale for defence production units is fundamentally different. In defence enterprises production is generally geared to accomplish a 'militarytechnological optimum', while with civilian companies the aim is to reach 
'market-value maximum'. At the former, efforts are made to raise the special utility value of the product, that is, the capacity to destroy or to avoid being destroyed. Every other aspect of the process is usually subordinate to this main principle. Civilian companies, on the contrary, try to raise the exchange value and, ultimately, their levels of profit. Other dimensions are subordinate to these goals.

Low defence production runs and duplicated research coupled with escalating production costs, has inevitably led to uncompetitiveness and questionable "strategic viability". Similarly, traditional supplier-buyer relationships have exacerbated this situation where the nature of the European defence industry's relationship with national governments particularly among prime systems manufacturers, has tended to foster a dependent corporate culture leading to inadequate exposure to market forces and independent political control

The culture of a defence company is, in general, agreed upon as its heaviest burden to be overcome in a change process. Smith and Smith (1992) singled out defence culture as a key inhibiting factor in the defence firm's ability to adjust to the changing military environment in the mid-80s; that is, when military spending had already begun to decline. Larger defence firms with highly autonomous subsidiary management appear to suffer significant 'culture gaps' that inhibit lateral technology transfers. This is shaped by traditional government buying behaviour and results in distinctive organisational structures and culture. For the smaller defence contractor, such major organisational influences are less likely to be present, although organisational processes and structure are inevitably influenced via the same strict demands for quality and technological superiority (Kenny, 1992).

For many companies in the free market economies a main opportunity is, and has been, to use east and central Europe as a possible production base for sales in the West, to tap the skills of the workforce, to take advantage of the country's natural resources and to deliver the subsequent output through existing channels in the West and elsewhere (Kenny and Trick, 1995). In light of previous analysis, not all of these motives seem compatible given the special nature of the defence industries and the interesting mix of political and economic forces at play. Indeed, in spite of the assumed disparity in technological progress and extent of use of so-called modern management techniques, defence companies from both sides of the east-west divide appeared to have shared similar experiences and to have adopted similar organisational traits.

Additionally, in the transformation of the political and economic systems, many ECE defence enterprises became subject to a double transition from protected to exposed and from state-owned to private or quasi private enterprises. In the past, managers had not been required to address economic problems nor were they obliged to address problems outside their immediate micro-environment, since their interests were well represented at higher levels. In the crisis, however, they 
were forced to address these questions. Kiss points out that whatever specific method of adjustment firms chose, coping inevitably involved two main elements: (a) getting acquainted with the basic elements of economic management; and (b) trying to influence the wider social and economic conditions in which they had to act (p167).

Thus, those firms that have managed to survive might well have much to offer their western counterparts in the way of useful management skills. What is generally sought through collaboration is the best commitment to future investment in restructuring and the biggest transfers of technology, management and marketing skills. The best joint venture deals are those which are likely to guarantee both the highest number of secure jobs and expedient integration of the more recently privatised enterprise into the global economy as a hard currency earning asset.

For ECE enterprises, such co-operation would not only represent a potential source of income, but also a means to implement positive backward linkages, new know-how, technology, methods of organizing production and/or establishing systematic market contacts with longer-term prospects. For the west, there is the additional insurance against what Rowold (1994) regarded as a possible threat of competition originating from former Warsaw Pact countries, bidding at extremely low prices.

Having relied heavily on government "cushioning" in the past, many defence companies, both west and east European, have to deal with questions of strategy adjustment, international alliances, segmentation and positioning and technological leadership and scale economies. This requires a re-evaluation of their level of vertical integration from a cost-minimising and competitionoriented perspective and consideration of private-venture developments, as procurement of commercially available equipment becomes an option of increasing attractiveness for governments.

Vertical integration and technology advanced together affect the structure of the industry, often to the detriment of the smaller defence enterprises. Systems integrators tend to survive easier than suppliers of sub-assemblies and the trend towards Government purchasing of existing and "affordable" products rather than engaging in long, costly and high risk developments only will often favour the fewer, larger organisations.

The demands on east European managers in the reforming countries were particularly severe given the pressures brought about by the environmental changes and the unpreparedness both in terms of structure and skills. Blatiak (1992) described the extent of the internal and external problems facing these managers (see figure 2) and put the situation in the context of a need for stability and recovery strategies. One of the most difficult tasks in the development process was to bring about the revolution in attitudes needed to transform the 
authoritarian, production-first mentality of the old management structures, while maximising transfers of technology, management and marketing skills.

Jackson (1996:17) raised the major question of: 'how fast, under any conditions, can former SOEs (state owned enterprises) acquire organizational capabilities suited to modern business, especially given the difficult problems faced of both micro-structuring and macro-economic reduction in aggregate demand?' $\mathrm{He}$ pointed out that once such capabilities have been conditioned in highly stable systems, they can be changed only very slowly. Additionally, a sudden, radical change in the economic environment will lead to 'much poorer economic performance during the protracted and difficult process of changing organizational routines and reallocating management'.

\section{Figure 2 The East European Business Environment}

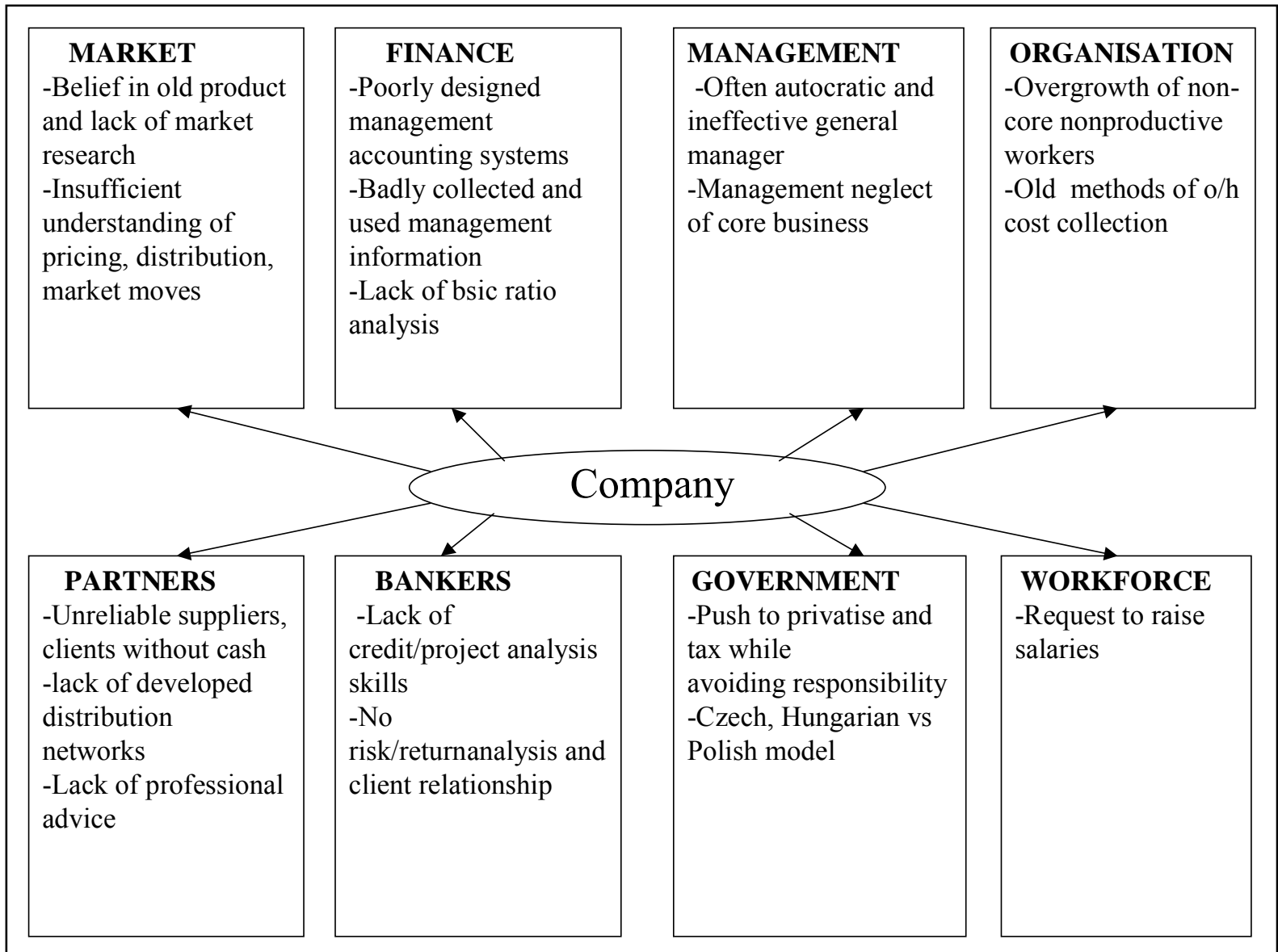

Source: Adapted from Blatiak (1992)

The major conflicts in West and east Europe partnerships have been identified by Cattaneo (1992) as different interpretations of basic business concepts, different view of management style, and different views on the roles of partners. She cites the negative connotations of the terms 'market' and 'profit' and the association with chaos and social injustice, in relation to west European and Russian join ventures. This is shown to be further exacerbated by the limited, 
continued experience of the illegal parallel economy which can hardly be complimentary to the idea of a market economy.

The differing viewpoints of potential joint venture partners obviously has implications for the marrying of the two corporate cultures involved. The desire and propensity for each side to maintain its own culture and the relative attractiveness of the cultures will have a bearing on the type and stability level of the acculturation process that subsequently takes place (see figure 3 )

Figure 3 Framing a Joint Venture

Desire to Maintain Own Culture

\begin{tabular}{|c|c|c|c|}
\hline & & & \\
\hline \multirow{3}{*}{$\begin{array}{l}\text { The Culture of } \\
\text { the Partner }\end{array}$} & & High & Low \\
\hline & Attractive & Integration & Assimilation \\
\hline & Not Attractive & Separation & Deculturation \\
\hline
\end{tabular}

\section{Source: Cattaneo (1992)}

However, there is some evidence east-west alliances can facilitate the transformation process, in spite of the acculturation problem. Robinson and Tomczak-Stepien (2000) in quoting an example of a commercially successful Polish enterprise, pointed to FDI as a key factor in its transformation. Their findings showed that the firm had 'undergone a radical transformation in all aspects of its operation and....could be said to approximate to an entrepreneurial, market driven organisational culture'. Practically all its innovations which comprised 'production technology, logistic systems, integrated computer information systems, managerial techniques and processes' had been transferred from the parent company had been 'influential in hastening successful adjustment to a market economy'.

According to Day (1999), customer-orientation and delivery of superior customer value will be subordinated in a strong sales, technology, or internallyoriented culture and marketing's role will be weaker. For defence companies, east or west, this is probably a more significant issue given the need to move away from reliance on limited domestic (defence) markets, particularly as most if not all, are declining. It could be said that defence companies by the very nature of the traditional monopsonistic markets they serve, are finely tuned to the customer; however, it has been established above, that such organisations in general, have tended to lack a marketing-orientation and a 'responsive culture'.

Accepting the differences between east-west management practices and experiences of environmental turbulence and recognising that individual defence firms will have their own specific culture, a number of common traits have been identified, both at industry and company level. Thus, some attempt to generalise 
on issues of industry influences, culture and change is justifiable and these are shown in figure 4.

The organisational impact of the industry characteristics will obviously vary according to the individual firm's level of, and reliance on, defence business; e.g., the contribution to overall profits, extent of divisionalisation if any, processes, etc. However, it is assumed there will be a 'baseline' impact on management, structure and processes for most firms, whatever the level. The resulting culture is likely to adversely affect change effectiveness for a number of strategic options, including diversification, conversion and market, as previously highlighted. Even if we limit the weakness analysis to one of marketing, in Day's terms the penalty is substantial as this provides:

the expertise in market sensing, customer linking, and channel binding to keep the organisation continuously appraised of opportunities and threats in the market, defines and articulates the value strategy, provides aids for navigation through market turbulence and provides the rationale for co-ordinating the core processes.

\section{Conclusions}

In the longer term European governments are faced with limited options with respect to their defence industries. As defence spending continues to fall, defence companies will have to develop stronger civilian activities and/or address the remaining market niches which are likely to call for more sophisticated, flexible weapons. The resulting consolidation is likely to lead to pressures to protect the few emerging 'European champions' and indeed, a single European defence industry may well precede ultimate, total economic and political unity

The specialised nature of defence equipment and the inherent organisational obstacles make the search for alternative products and markets that much more problematic - even if the opportunities for conversion present themselves in abundance, which clearly is not the case. Perhaps the main saving grace is the present attention given to the European aerospace industry, where the pooling of activity coupled with the experience of developing dual-use technologies facilitates exploitation on a global scale. 
Figure 4 Industry Characteristics and Impact on Firm Culture

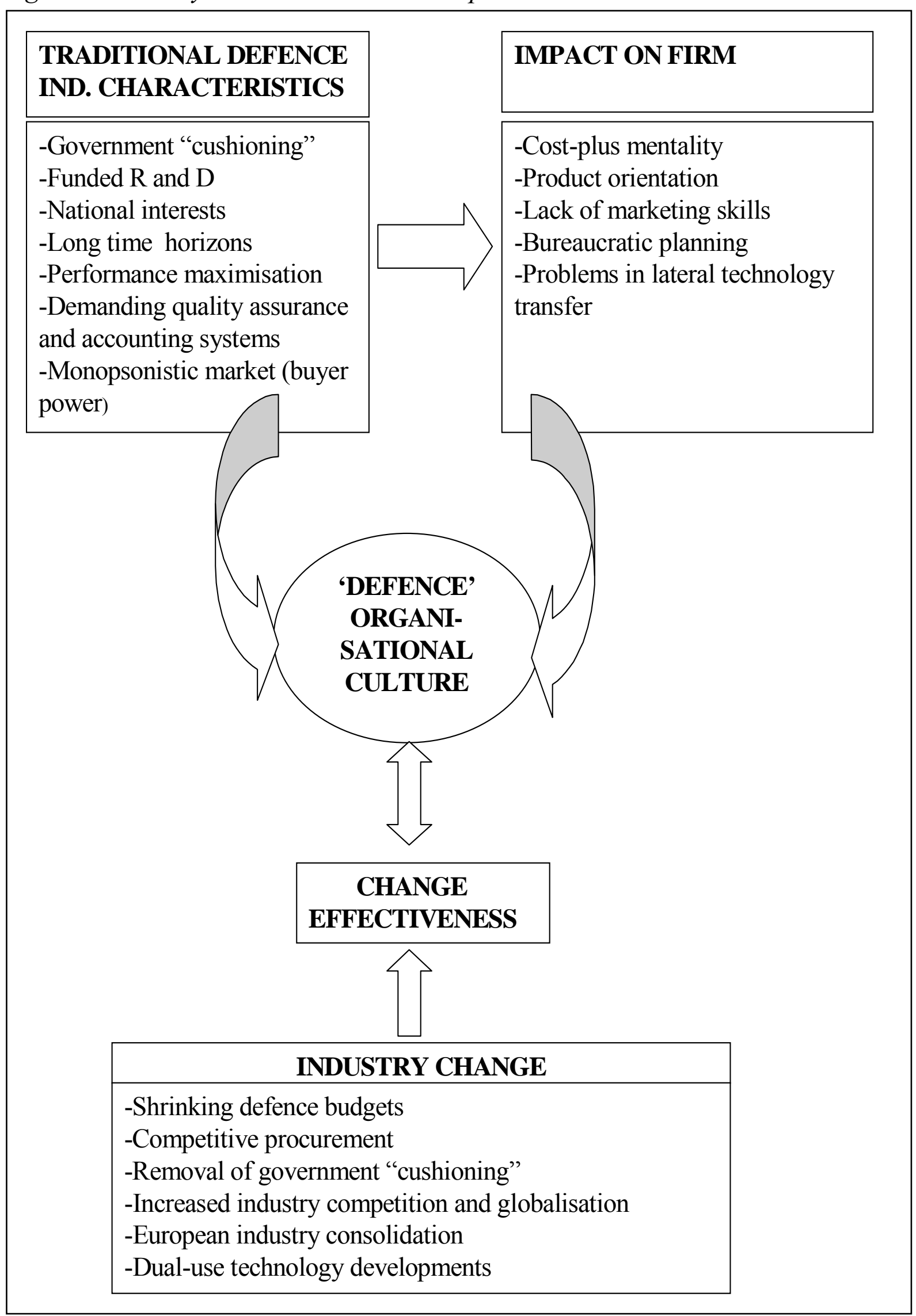

Source: Adapted from Kenny and Stessen (1996) 
What the Central European nations may add to the equation is debatable. The first priority of course, is their full integration into NATO and that will presumably further enhance business opportunities for western European defence companies. It is evident that at least Poland and the Czech Republic are able in turn, to make some contribution to a wider European defence industry, but at the same time bring with them the problems already associated with conversion and diversification.

The potential integration of east and central European defence industry adds a new dimension to the culture equation. Moving from a command-controlled economy has resulted in the requirement for the region to cope simultaneously with technological modernisation, liberalisation and market and industry restructuring. Where, following transition, ECE defence enterprises were merely subject to loss of state cushioning and to coping with sudden exposure to market forces, integration 'acculturation' will involve having to take on the additional burden of adapting to the peculiarities of the European defence industry and its partners. However, it is evident that the military-industrial complexes in both east and west Europe have developed, at least in the historic sense, many similar characteristics and this shared experience will no doubt help the acculturation process.

Of course, the problems are not confined to cultural differences for while for European defence programmes have clearly established the basis for joint procurement, they generally have given rise to a range of cost, technical and management problems; a process exacerbated by partner counties' insisting on applying the juste retour principle to sharing out domestic production, in spite of the economic logic of such arrangements. Hopefully, for the ECE industry, that principle may continue to be effective.

The increasing global perspective of the defence industry and market, together with the conversion /diversification alternative, has placed demands on different company core skills in the face of mounting competitive pressures. It seems to depend a good deal on the individual company's characteristics and history, and to what extent the extant defence culture will inhibit change towards a more "commercial" way of doing business; or whether this defence culture is in general prevailing, but may readily be circumvented if the environmental situation calls for that.

In the framework of alliances, industrial co-operation between western partners may become easier, at least in some spheres of defence production and should increase external interest in the products of local ECE defence manufacturers. Indeed, encouragement of FDI is likely to benefit both sides; on the one hand it seems, in furthering the transformation process both at the industry and firm level and on the other, greater global competitiveness and a much tighter European security. Whether such alliances and their associated organisational problems will prove easy or difficult to manage - particularly under the umbrella 
of economic reform and industry restructuring - is questionable. Certainly, the evidence to date, taking into account comparative research in non-defence sectors, is conflicting and merely serves to emphasise the unique situation of the defence industry and the paucity of research in this area.

\section{References}

Arthur D Little (1995). Competing for Defence Exports- Building a World-Class Sales and Marketing Capability, Paper on European Defence/Aerospace, London

Blatiak, A (1992). Designing a Successful Recovery Strategy, AMED Conference on Management Development Needs in Central and Eastern Europe, London Business School, November.

Cattaneo, E (1992), Managing Joint Ventures in Russia: Can the Problems be Solved? Long Range Planning, Vol. 25 No 5, October, pp 68-72.

Cechak, O., J Selesovsky, and M Stembera (1993). "Czechoslovakia: Reduction in Arms Production in a Time of Economic and Political Transformation" in: H. Wulf, ed., Arms Industry Limited, Oxford University Press

Cook, P (1999), "An Uncertain Future for Central European Defence Industries", ISIS Briefing Paper No. 20, January

Day, G (1999). Aligning Organizational Structure to the Market, Business Strategy Review, Vol. 10 No 3, Autumn, pp 33-46

Defence Systems Daily (2000), "Western European Aerospace \& Defence Industries - The Ownership Jigsaw", 4 January http:defence-data.com

Gray, I G (1999). "Can FLA Bring About a New Approach to Defence Procurement in Europe?” in: P Lawrence, D Braddon and P Dowdall, Strategic Issues in the European Aerospace Industry, Ashgate Publishing, pp 145-164

International Institute for Strategic Studies (1995, 1998). The Military Balance, IISS

Jackson, M (1996), "Property Rights, Company Organisation and Governance in the Transition" in: M Jackson and V Biesbrouk, (eds)., Marketization, Restructuring and Competition in Transition Industries of Central and Eastern Europe, pp 1-34, Avebury

Kenny, B and L Stessen (1996). UK and German Defence Industry Change: Some Perspectives on Strategic Marketing, Journal of Marketing Management, Vol. 12, No 6 pp 561-579

Kenny, B and RR Trick (1995). Reform and Management Education - A Case from the Czech Republic, Journal of East-West Business, Vol 1 No 1 pp 69-95 (with R R Trick)

Kenny, B (1992). The Defence Industry and High Technology SME's, in: Welford, R. (Ed.) Small Business and Small Business Development, European Press, pp 63-68

Kiss, Y (1997). The Defence Industry in East-Central Europe. Restructuring and Conversion, Oxford University Press,

Perczynski, M, P Wieczorek and K Zukrowska (1995). Country Survey V: Poland and its Arms Industry, Defence and Peace Economics, Vol. 6 No 1 pp 59-74 
Robinson, I and B Tomczak-Stepien (2000), Cultural Transformation at Enterprise Level: Case Study Evidence from Poland, Journal for East European Management Studies, Vol. 5, No. 2, pp 130-151

Rowold, M (1994). Russische Waffen wieder gefragt. Welt, Oct 12.

SIPRI (1998). Yearbook - Armaments, Disarmament and International Security, Oxford University Press

Smith, R and D Smith (1992). Corporate Strategy, Corporate Culture and Conversion; Adjustment in the Defence Industry, Business Strategy Review, Volume 3, No 2, pp 45-58.

Szayna, T.S. (1995). "Defense Conversion in East Europe", in: J P Hardt and R Kaufman, Eds. East-Central European Economies in Transition, M E Sharp Inc., pp 133-146 